ISSN 1392-3196 / e-ISSN 2335-8947

Zemdirbyste-Agriculture, vol. 108, No. 1 (2021), p. 57-62

DOI 10.13080/z-a.2021.108.008

\title{
Evaluation of the biological-economic and biochemical traits of promising Ribes nigrum hybrids in Estonia
}

\author{
Ave KIKAS, Peeter LAURSON, Asta-Virve LIBEK \\ Estonian University of Life Sciences, Institute of Agricultural and Environmental Sciences \\ Polli, Viljandi distr., Estonia \\ E-mail: ave.kikas@emu.ee
}

\begin{abstract}
The evaluation of promising hybrids of blackcurrant (Ribes nigrum L.) was carried out in 2016-2018 in SouthEstonia at Polli Horticultural Research Centre of the Estonian University of Life Sciences. The objective of the Estonian blackcurrant breeding programme is to produce cultivars that are winter hardy, resistant to gall mite (Cecidophyopsis ribis Westw.) and gooseberry mildew (Sphaerotheca mors-uvae (Schw.) Berk.), well suited to machine harvesting, with good yield and quality of fruits. The evaluation plot was established in the autumn of 2014. Twenty-four blackcurrant promising hybrids from the Estonian blackcurrant breeding programme and a new Estonian cultivar 'Mairi' as the standard were evaluated for beginning of flowering and fruit ripening (expressed in growing degree-days, GDD), winter hardiness, resistance to diseases and pests (expressed in scores 1-9), number of fruits per cluster, yield (kg per bush), weight of fruit and content of the soluble solids ( ${ }^{\circ}$ Brix). Fruits were analysed for titratable acids, ascorbic acid, anthocyanins and polyphenols. The evaluation revealed the best black-fruited genotypes to be Nos 3-08-1 ('Ben Alder' $\times$ 'Titania'), 7-08-1, 7-08-2 ('Intercontinental' $\times$ 'Pamyat Vavilova') and 15-09-1 ('Asker' free pollination), and the green-fruited genotype No. 8-09-3 ('Öjebyn' × 'Mairi'). All these genotypes are winter hardy and visually resistant to gall mite and gooseberry mildew. The first four produced good yields and large fruits.
\end{abstract}

Key words: anthracnose, blackcurrant genotypes, fruit weight, winter hardiness, yield.

\section{Introduction}

Blackcurrant (Ribes nigrum L.) is an important soft fruit crop cultivated commercially in moderatetemperature regions of the world (Brennan, 2008; Sasnauskas et al., 2009; Pluta, Żurawicz, 2014; Woznicki et al., 2015; Strautina et al., 2020). Blackcurrant breeding is carried out in different countries; classical breeding is integrated with new techniques and breeding methods (Mažeikienè et al., 2019; Stanys et al., 2019; Jarret et al., 2020).

In Estonia, blackcurrant breeding has a long tradition dating back to the beginning of last century, stimulated recently in 2000 with financial support from the government. The aim of the breeding programme is to produce cultivars that are winter hardy, resistant to gall mite (Cecidophyopsis ribis Westw.) and gooseberry mildew (Sphaerotheca mors-uvae (Schw.) Berk.), well suited to machine harvesting, with good yield and fruit quality. These traits are also important in other blackcurrant breeding programmes (Sasnauskas et al., 2009; 2013; Masny et al., 2018). In the $21^{\text {st }}$ century, the blackcurrant cultivars 'Varmas' (2003), 'Ats', 'Almo', 'Elo', 'Karri' (2008), 'Elmar' (2018), 'Asker' and 'Mairi'
(2019) have been developed and registered under the breeding programme. 'Varmas', 'Elo', 'Karri' and 'Mairi' are very good dessert cultivars (Kikas et al., 2017; 2019); the cultivar 'Asker' has a high and stable ascorbic acid content (Kaldmäe et al., 2013; Kikas et al., 2017).

The purpose of this study was to evaluate 24 promising hybrids of blackcurrant for biologicaleconomic properties: beginning of flowering and fruit ripening, winter hardiness, disease and pest resistance, flower and young fruit drop, yield, number of fruits per cluster, and biochemical properties of the fruit and select potential cultivars.

\section{Materials and methods}

The evaluation of promising blackcurrant (Ribes nigrum L.) hybrids was carried out in 2016-2018 in South-Estonia at Polli Horticultural Research Centre $\left(58^{\circ} 7^{\prime} 26^{\prime \prime} \mathrm{N}, 25^{\circ} 32^{\prime} 43^{\prime \prime} \mathrm{E}\right)$ of the Estonian University of Life Sciences Institute of Agricultural and Environmental Sciences. The evaluation plot was established in the autumn of 2014 with one-year old plants. Bushes were in plots of $3 \times 0.8 \mathrm{~m}$ with three replicates of each cultivar.

Please use the following format when citing the article:

Kikas A., Laurson P., Libek A.-V. 2021. Evaluation of the biological-economic and biochemical traits of promising Ribes nigrum hybrids in Estonia. Zemdirbyste-Agriculture, 108 (1): 57-62. DOI 10.13080/z-a.2021.108.008 
For three consecutive years, 24 promising hybrids from the Estonian blackcurrant breeding programme and the new cultivar 'Mairi' as the standard were evaluated (Table 1).

Table 1. The pedigree of the tested blackcurrant genotypes

\begin{tabular}{clc}
\hline $\begin{array}{c}\text { Genotype } \\
\text { No. }\end{array}$ & \multicolumn{1}{c}{ Parentage } & $\begin{array}{c}\text { Colour } \\
\text { of fruit }\end{array}$ \\
\hline 'Mairi' & Öjebyn $\times$ Kantata 50 & black \\
$6-09-1$ & Ben Sarek $\times$ Asker & black \\
$10-09-1$ & Mairi $\times$ Öjebyn & green \\
$10-09-2$ & Mairi $\times$ Öjebyn & glack \\
$8-09-3$ & Öjebyn $\times$ Mairi & black \\
$9-09-1$ & Asker $\times$ Karri & black \\
$1-08-2$ & Titania $\times$ Ben Sarek & black \\
$1-08-1$ & Titania $\times$ Ben Sarek & black \\
$3-08-1$ & Ben Alder $\times$ Titania & black \\
$7-08-1$ & Intercontinental $\times$ Pamyat Vavilova & black \\
$7-09-1$ & Asker $\times$ Ben Sarek & black \\
$8-09-1$ & Öjebyn $\times$ Mairi & black \\
$7-08-3$ & Intercontinental $\times$ Pamyat Vavilova & black \\
$7-08-2$ & Intercontinental $\times$ Pamyat Vavilova & black \\
$11-09-3$ & Mairi $\times$ Asker & black \\
$11-09-4$ & Mairi $\times$ Asker & black \\
$12-09-1$ & Ben Sarek $\times$ Karri & black \\
$12-09-2$ & Ben Sarek $\times$ Karri & black \\
$13-09-2$ & Mairi $\times$ Ben Sarek & black \\
$13-09-1$ & Mairi $\times$ Ben Sarek & black \\
$15-09-1$ & Asker free pollination & black \\
$8-08.3$ & Titania $\times$ Ben Connan & black \\
$8-08-9$ & Titania $\times$ Ben Connan & black \\
$5-09-2$ & Mairi $\times$ Ben Connan & black \\
$5-09-1$ & Mairi $\times$ Ben Connan & \\
\hline & & Man
\end{tabular}

Each spring, $300 \mathrm{~kg} \mathrm{ha}^{-1}$ of the complex fertilizer Cropcare 6-14-23 (Kemira OY) was applied along the rows. The rows were mulched with milled peat, and inter-row spaces were grown to grasses and mown four times during the summer. The plantation was set up on a moderately heavy, loamy soil with good drought resistance, so no irrigation system was required. No pesticides were used in the plantation.
The following characteristics of the blackcurrant genotypes were recorded: the beginning of flowering ( $10 \%$ of flowers fully open), the beginning of fruit ripening (10\% of fruits with full colour). Based on this, the growing degree-days (GDD) to anthesis and start of ripening were calculated according to equation (McMaster, Wilhelm, 1997; Aydin et al., 2019):

$$
\mathrm{GDD}=\left(\mathrm{T}_{\max }+\mathrm{T}_{\min } / 2\right)-\mathrm{T}_{\text {base }} \text {, }
$$

where $T_{\max }$ and $T_{\min }$ are daily max and min temperatures, $T_{\text {base }}$ is base temperature. A base temperature of $5^{\circ} \mathrm{C}$ was used (Dalton, Hummer, 2010). This is the beginning point of the GDD calculation.

The following parameters were recorded: flower and young fruit drop during full bloom, the number of flowers in 20 random clusters per bush and the number of fruits remaining on the clusters three weeks after flowering. Based on the data collected, the percentage of flower and young fruit drop was calculated, and yield (kg bush $^{-1}$ ) and fruit weight (calculated by 100 berry weight, g) were recorded.

Winter damage was evaluated on a scale of 1-9 points each spring during the intensive growth of leaves. Also, damage by anthracnose (Drepanopeziza ribis Kleb.), gall mite (scores 1-9: 1 - no visible symptoms of infection, 9 - more than $75 \%$ damaged buds) and gooseberry mildew (scores 1-9: 1 - no visible symptoms of infection, 9 - more than $75 \%$ damaged leaves) was recorded.

The data on average air temperature and precipitation per ten days for May, June and July of the testing years are given in Table 2.

The winter of 2015-2016 was favourable for the wintering of blackcurrant genotypes, and damage was absent. The first ten-day period of May was very warm with no precipitation. The spring and summer of 2017 were quite cool. In 2017-2018, winter temperature after quite a warm period fell to $-20^{\circ} \mathrm{C}$. The summer of 2018 was very dry and hot.

Table 2. Average air temperature and amount of precipitation during May to July in 2016, 2017 and 2018

\begin{tabular}{|c|c|c|c|c|c|c|c|}
\hline \multirow{2}{*}{ Month } & \multirow{2}{*}{$\begin{array}{l}\text { Ten-day } \\
\text { period }\end{array}$} & \multicolumn{3}{|c|}{ Average air temperature per ten days ${ }^{\circ} \mathrm{C}$} & \multicolumn{3}{|c|}{ Precipitation mm } \\
\hline & & 2016 & 2017 & 2018 & 2016 & 2017 & 2018 \\
\hline \multirow[t]{3}{*}{ May } & I & 14.0 & 6.7 & 11.8 & 0.0 & 3.3 & 17.4 \\
\hline & II & 12.4 & 10.3 & 16.3 & 20.4 & 0.6 & 8.0 \\
\hline & III & 16.0 & 13.5 & 17.2 & 0.0 & 9.9 & 0.0 \\
\hline \multirow[t]{3}{*}{ June } & $\mathrm{I}$ & 14.1 & 12.3 & 14.0 & 5.0 & 21.1 & 12.1 \\
\hline & II & 14.3 & 15.7 & 17.4 & 107.6 & 15.6 & 17.1 \\
\hline & III & 19.7 & 13.8 & 15.2 & 18.1 & 24.2 & 31.4 \\
\hline \multirow[t]{3}{*}{ July } & I & 16.8 & 14.4 & 15.7 & 48.1 & 31.8 & 15.1 \\
\hline & II & 17.3 & 15.4 & 21.7 & 18.6 & 42.5 & 2.5 \\
\hline & III & 19.8 & 16.9 & 22.9 & 8.5 & 5.1 & 22.2 \\
\hline
\end{tabular}

In the juice, the content of soluble solids (\%) was determined with a refractometer ABBE WAY-1S (Optic Ivymen System, Spain), titratable acids (\%, citric acid equivalent) - by titration with $0.1 \mathrm{M} \mathrm{NaOH}$ and ascorbic acid (mg $100 \mathrm{~g}^{-1}$ fresh weight $-\mathrm{FW}$ ) - according to T05-HPLC method (Williams et al., 1973). The content of total polyphenols (mg $100 \mathrm{~g}^{-1} \mathrm{FW}$, chlorogenic acid equivalent) and total anthocyanins (mg $100 \mathrm{~g}^{-1} \mathrm{FW}$, cyanidin-3-glucoside equivalent) were quantified using a Shimadzu Nexera X2 UHPLC-DAD System (Japan). Determination of ascorbic acid content was performed by the Tartu Laboratory of the Estonian Health Board. The remaining analyses were performed by the Biochemistry
Laboratory of Polli Horticultural Research Center of the Estonian University of Life Sciences.

The results were analysed by a two-way analysis of variance (ANOVA) and correlation analyses. To evaluate the effect of genotypes, the least significant differences $\mathrm{LSD}_{0.05}$ or $\mathrm{LSD}_{0.01}$ were calculated; different letters in tables mark significant differences at $p \leq 0.05$ or $p \leq 0.01$.

\section{Results and discussion}

Phenological traits. Weather conditions, in particular temperature, are an important factor for 
biological development and yield formation of plants. Plant phenology is better measured in growing degreedays (GDD, ${ }^{\circ} \mathrm{C}$-day) compared to other approaches such as time of year (McMaster, Wilhelm, 1997). The GDD required to start blackcurrant flowering depends on both growth conditions and genotype. The lowest GDD was in the cool spring in 2017 with an average for genotypes of only 81 GDD. In 2016 and 2018, it did not differ significantly from the genotypes averaging 127 and 139 GDD, respectively (Table 3). In 2017, the amount of GDD required for flowering was the smallest with flowering about ten days later than in 2016 and 2018.

Table 3. The growing degree-days (GDD) to the beginning of flowering and fruit ripening of blackcurrant genotypes

\begin{tabular}{|c|c|c|c|c|c|c|c|c|}
\hline \multirow{2}{*}{$\begin{array}{c}\text { Genotype } \\
\text { No. }\end{array}$} & \multicolumn{4}{|c|}{ GDD to flowering } & \multicolumn{4}{|c|}{ GDD to fruit ripening } \\
\hline & 2016 & 2017 & 2018 & average & 2016 & 2017 & 2018 & average \\
\hline 'Mairi' & 98 & 64 & 115 & $92 \pm 25.9 b$ & 695 & 705 & 732 & $711 \pm 19.2 \mathrm{~b}$ \\
\hline $6-09-1$ & 117 & 100 & 150 & $123 \pm 25.4 \mathrm{ab}$ & 800 & 728 & 792 & $773 \pm 39.6 \mathrm{ab}$ \\
\hline $10-09-1$ & 107 & 75 & 141 & $108 \pm 33.3 \mathrm{ab}$ & 774 & 716 & 743 & $744 \pm 29.2 b$ \\
\hline $10-09-2$ & 98 & 100 & 141 & $113 \pm 24.5 \mathrm{ab}$ & 800 & 728 & 778 & $769 \pm 37.1 \mathrm{ab}$ \\
\hline $8-09-3$ & 98 & 87 & 141 & $109 \pm 28.9 \mathrm{ab}$ & 738 & 716 & 806 & $753 \pm 46.7 b$ \\
\hline $9-09-1$ & 107 & 87 & 141 & $112 \pm 27.5 \mathrm{ab}$ & 786 & 728 & 765 & $759 \pm 29.4 \mathrm{ab}$ \\
\hline $1-08-2$ & 155 & 87 & 160 & $134 \pm 40.6 \mathrm{a}$ & 957 & 716 & 792 & $821 \pm 121.1 \mathrm{ab}$ \\
\hline $1-08-1$ & 141 & 87 & 150 & $126 \pm 34.1 \mathrm{ab}$ & 957 & 728 & 778 & $821 \pm 120.3 \mathrm{ab}$ \\
\hline $3-08-1$ & 147 & 75 & 141 & $121 \pm 40.9 \mathrm{ab}$ & 990 & 684 & 743 & $806 \pm 162.1 \mathrm{ab}$ \\
\hline $7-08-1$ & 147 & 67 & 134 & $116 \pm 42.9 \mathrm{ab}$ & 990 & 728 & 806 & $841 \pm 134.6 \mathrm{a}$ \\
\hline $7-09-1$ & 172 & 87 & 141 & $134 \pm 43.3 \mathrm{a}$ & 957 & 728 & 806 & $830 \pm 116.4 \mathrm{ab}$ \\
\hline 8-09-1 & 177 & 67 & 134 & $126 \pm 55.3 \mathrm{ab}$ & 889 & 705 & 806 & $800 \pm 91.8 \mathrm{ab}$ \\
\hline $7-08-3$ & 182 & 75 & 134 & $130 \pm 53.6 \mathrm{a}$ & 990 & 739 & 778 & $836 \pm 134.9 \mathrm{ab}$ \\
\hline $7-08-2$ & 182 & 67 & 115 & $122 \pm 57.4 \mathrm{ab}$ & 973 & 739 & 792 & $834 \pm 122.6 \mathrm{ab}$ \\
\hline $11-09-3$ & 98 & 67 & 134 & $100 \pm 33.6 \mathrm{ab}$ & 914 & 716 & 743 & $791 \pm 107.1 \mathrm{ab}$ \\
\hline $11-09-4$ & 117 & 87 & 141 & $115 \pm 27.3 \mathrm{ab}$ & 900 & 705 & 743 & $783 \pm 103.5 \mathrm{ab}$ \\
\hline $12-09-1$ & 127 & 87 & 134 & $116 \pm 25.6 \mathrm{ab}$ & 957 & 739 & 806 & $834 \pm 111.6 \mathrm{ab}$ \\
\hline $12-09-2$ & 90 & 75 & 141 & $102 \pm 35.0 \mathrm{ab}$ & 914 & 739 & 754 & $802 \pm 96.7 \mathrm{ab}$ \\
\hline $13-09-2$ & 127 & 75 & 134 & $112 \pm 32.5 \mathrm{ab}$ & 941 & 705 & 792 & $813 \pm 119.4 \mathrm{ab}$ \\
\hline $13-09-1$ & 90 & 87 & 141 & $106 \pm 30.7 \mathrm{ab}$ & 900 & 764 & 843 & $836 \pm 68.5 \mathrm{ab}$ \\
\hline $15-09-1$ & 136 & 87 & 141 & $121 \pm 30.0 \mathrm{ab}$ & 914 & 684 & 792 & $797 \pm 114.7 \mathrm{ab}$ \\
\hline $8-08-3$ & 141 & 87 & 141 & $123 \pm 31.2 \mathrm{ab}$ & 941 & 716 & 792 & $816 \pm 114.7 \mathrm{ab}$ \\
\hline $8-08-9$ & 136 & 100 & 160 & $132 \pm 29.8 \mathrm{a}$ & 941 & 764 & 818 & $841 \pm 90.8 \mathrm{a}$ \\
\hline $5-09-2$ & 90 & 64 & 125 & $93 \pm 30.2 \mathrm{~b}$ & 973 & 752 & 830 & $851 \pm 112.0 \mathrm{a}$ \\
\hline $5-09-1$ & 98 & 75 & 150 & $108 \pm 38.7 \mathrm{ab}$ & 927 & 728 & 754 & $803 \pm 108.3 \mathrm{ab}$ \\
\hline $\begin{array}{c}\text { Average } \\
\text { for genotypes }\end{array}$ & 127 & 81 & 139 & $116 \pm 30.6$ & 901 & 724 & 783 & $803 \pm 90.1$ \\
\hline
\end{tabular}

Note. In columns, different letters mark significant differences at $p \leq 0.05$.

According to Hummer and Dale (2010), currants need 160-200 GDD to start flowering, but in our experiment, it was much lower, especially in 2017. This may be due to the genotype differences (Krüger et al., 2011; Pluta, Pruski, 2012) and agroclimatic conditions (Pedersen, 2007; Yang et al., 2010), which play an important role in the development of blackcurrant plants. Cultivar 'Mairi' and genotype No. 5-09-2 needed the least GDD for flowering, 92 and 93 GDD, respectively, while genotypes Nos 1-08-2, 7-09-1, 7-08-3 and 8-08-9 required the most GDD (Table 2).

To start ripening, the fruits needed the highest amount of GDD in 2016 and the least amount in 2017, with a genotype average of 901 GDD and 724 GDD, respectively. The least amount of GDD was needed by the cultivar 'Mairi' and genotypes Nos 10-09-1 and 8-09-3 for the start of fruit ripening, and the differences between GDD over the years were relatively small. The genotypes Nos 7-08-1, 8-08-9 and 5-09-2 needed the most GDD for the beginning of fruit ripening, and the differences between GDD were relatively large between years. The early cultivar 'Mairi' and Nos 10-09-1 and 8-09-3 were shown to be early maturity genotypes, and Nos 7-08-1, 8-08-9 and 5-09-2 were late maturity genotypes (Kikas et al., 2019). Winter damage occurred only in 2018 for the genotypes Nos 11-09-3 and 12-09-1, all with 7 points. The bushes recovered well.

Physiological traits. During the experimental years, flower and young fruit drop was not large, and the differences between the years were small with genotype means of $15.5,10.5$ and $11.0 \%$, respectively. It was the highest in the Nos 9-09-1 (22.5\%) and 1-08-1 (22.7\%), but less than $20 \%$ in the remaining genotypes (Table 4 ).

There was a positive correlation $(r=0.56)$ between the amount of GDD required for flowering and the onset of fruiting. Correlation analysis revealed only a weak positive relationship $(r=0.14)$ between flower and young fruit drop and GDD to flowering. Clusters had the most fruits in 2016, 2018 and the least in 2017, the amount of GDD required for flowering, and fruit ripening was the smallest with $6.8,6.2$ and 5.5, respectively. The longest clusters were on genotypes Nos 8-09-1 and 11-09-4 with 7.8 and 7.7 fruits, respectively. One of the parents of both genotypes is cultivar 'Mairi', which also has relatively long clusters. There was a weak negative relationship $(r=-0.15)$ between the number of fruits per cluster and flower and young fruit drop.

Economic traits. The average yield of genotypes was the highest in 2018 and the lowest in 2016 with 1.1 and $2.4 \mathrm{~kg} \mathrm{bush}^{-1}$, respectively. This is also logical, as bushes were still young in 2016, the genotypes Nos 3-08-1, 7-08-3, 7-08-2, 7-08-1 and 15-09-1 produced good yields in the first testing year with $2,1.8,1.6,1.5$ and $1.5 \mathrm{~kg}$ bush $^{-1}$, respectively. The yield of 'Mairi' in 2016 was $1.5 \mathrm{~kg} \mathrm{bush}^{-1}$. On average over the test years, the highest yield was from No. 7-08-1 (2.5 kg bush-1), followed by Nos 3-08-1 and 7-08-2 (2.3 kg bush $\left.{ }^{-1}\right)$, and Nos 7-08-3 and 15-09-1 (2.1 kg bush ${ }^{-1}$ ) (Table 4). The yield of 'Mairi' was $2.1 \mathrm{~kg}$ bush $^{-1}$.

One of the parents of genotypes Nos 7-08-1, 7-08-2 and 7-08-3 was cultivar 'Pamyat Vavilova', which has proved to be a good and stable yielding cultivar in 
Table 4. The physiological traits of blackcurrant genotypes

\begin{tabular}{|c|c|c|c|c|c|}
\hline $\begin{array}{l}\text { Genotype } \\
\text { No. }\end{array}$ & $\begin{array}{c}\text { Yield } \\
\mathrm{kg} \mathrm{bush}^{-1}\end{array}$ & $\begin{array}{l}\text { Number of fruits } \\
\text { per cluster }\end{array}$ & $\begin{array}{l}\text { Fruit weight } \\
\qquad \mathrm{g}\end{array}$ & $\begin{array}{c}\text { Flower and young fruit } \\
\text { drop } \%\end{array}$ & $\begin{array}{l}\text { Damage by } \\
\text { anthracnose }^{1}\end{array}$ \\
\hline 'Mairi' & $2.1 \pm 0.87 \mathrm{ab}$ & $6.7 \pm 1.62 \mathrm{ab}$ & $1.5 \pm 0.36 \mathrm{~b}$ & $11.3 \pm 12.4 \mathrm{~b}$ & $2.7 \mathrm{~cd}$ \\
\hline $6-09-1$ & $1.7 \pm 1.0 \mathrm{bc}$ & $5.9 \pm 1.15 \mathrm{~b}$ & $1.2 \pm 0.06 \mathrm{bd}$ & $8.6 \pm 1.75 b$ & $2.7 \mathrm{~cd}$ \\
\hline $10-09-1$ & $1.4 \pm 0.45 \mathrm{bc}$ & $6.3 \pm 0.7 \mathrm{ab}$ & $0.7 \pm 0.06 \mathrm{f}$ & $14.8 \pm 7.3 \mathrm{ab}$ & $4.3 \mathrm{ab}$ \\
\hline $10-09-2$ & $1.6 \pm 1.10 \mathrm{bc}$ & $7.3 \pm 0.92 \mathrm{ab}$ & $0.9 \pm 0.10 \mathrm{e}$ & $13 \pm 6.8 b$ & $2.7 \mathrm{~cd}$ \\
\hline $8-09-3$ & $1.3 \pm 0.64 \mathrm{c}$ & $5.6 \pm 0.26 \mathrm{~b}$ & $1.0 \pm 010 \mathrm{e}$ & $7.3 \pm 5.1 \mathrm{~b}$ & $3.3 \mathrm{bc}$ \\
\hline $9-09-1$ & $1.6 \pm 0.49 \mathrm{bc}$ & $6.5 \pm 0.51 \mathrm{ab}$ & $1.4 \pm 0.15 \mathrm{bc}$ & $22.5 \pm 16.0 \mathrm{a}$ & $4.3 \mathrm{ab}$ \\
\hline $1-08-2$ & $2.0 \pm 0.67 \mathrm{ab}$ & $4.9 \pm 1.2 \mathrm{~b}$ & $1.3 \pm 0.17 \mathrm{c}$ & $16.6 \pm 3.3 \mathrm{ab}$ & $2.7 \mathrm{~cd}$ \\
\hline $1-08-1$ & $1.5 \pm 0.76 \mathrm{bc}$ & $6.2 \pm 0.30 \mathrm{ab}$ & $1.1 \pm 0.10 \mathrm{~d}$ & $22.7 \pm 5.4 \mathrm{a}$ & $3.7 \mathrm{~b}$ \\
\hline $3-08-1$ & $2.3 \pm 0.61 \mathrm{ab}$ & $5.2 \pm 0.97 \mathrm{~b}$ & $1.4 \pm 0.26 \mathrm{bc}$ & $18 \pm 1.6 \mathrm{ab}$ & $4.3 \mathrm{ab}$ \\
\hline $7-08-1$ & $2.5 \pm 1.20 \mathrm{a}$ & $6.3 \pm 1.60 \mathrm{ab}$ & $1.5 \pm 0.23 \mathrm{~b}$ & $11 \pm 2.4 \mathrm{~b}$ & $4.3 \mathrm{ab}$ \\
\hline $7-09-1$ & $2.0 \pm 0.70 \mathrm{ab}$ & $5.7 \pm 1.03 \mathrm{~b}$ & $1.5 \pm 0.15 b$ & $8.8 \pm 5.8 b$ & $2.7 \mathrm{~cd}$ \\
\hline $8-09-1$ & $1.5 \pm 0.66 \mathrm{bc}$ & $7.8 \pm 0.99 \mathrm{a}$ & $1.1 \pm 015 \mathrm{c}$ & $5.3 \pm 1.5 b$ & $2.3 \mathrm{~d}$ \\
\hline $7-08-3$ & $2.1 \pm 0.50 \mathrm{ab}$ & $7.1 \pm 1.87 \mathrm{ab}$ & $1.4 \pm 0.10 \mathrm{bc}$ & $7.3 \pm 3.5 b$ & $4.3 \mathrm{ab}$ \\
\hline $7-08-2$ & $2.3 \pm 0.76 \mathrm{ab}$ & $6.9 \pm 1.17 \mathrm{ab}$ & $1.6 \pm 0.20 \mathrm{ab}$ & $8.7 \pm 3.1 \mathrm{~b}$ & $4.3 \mathrm{ab}$ \\
\hline $11-09-3$ & $1.5 \pm 0.9 \mathrm{bc}$ & $6.3 \pm 0.46 \mathrm{ab}$ & $1.7 \pm 0.06 \mathrm{a}$ & $14 \pm 4.8 \mathrm{ab}$ & $3 \mathrm{c}$ \\
\hline $11-09-4$ & $2.0 \pm 1.20 \mathrm{ab}$ & $7.7 \pm 0.15 \mathrm{a}$ & $1.1 \pm 0.15 \mathrm{~d}$ & $8.9 \pm 5.0 b$ & $3 \mathrm{c}$ \\
\hline $12-09-1$ & $1.9 \pm 0.61 \mathrm{~b}$ & $5.7 \pm 0.76 b$ & $1.4 \pm 0.02 \mathrm{bc}$ & $11.4 \pm 9.5 \mathrm{~b}$ & $3 \mathrm{c}$ \\
\hline $12-09-2$ & $1.4 \pm 0.53 \mathrm{bc}$ & $5.7 \pm 0.96 b$ & $1.4 \pm 0.21 \mathrm{bc}$ & $13.6 \pm 8.9 \mathrm{ab}$ & $3.3 \mathrm{bc}$ \\
\hline $13-09-2$ & $1.7 \pm 0.96 \mathrm{bc}$ & $6.8 \pm 0.42 \mathrm{ab}$ & $1.2 \pm 0.15 \mathrm{~cd}$ & $7.7 \pm 3.0 \mathrm{~b}$ & $3.7 \mathrm{~b}$ \\
\hline $13-09-1$ & $1.9 \pm 1.20 \mathrm{~b}$ & $5.7 \pm 1.08 \mathrm{~b}$ & $1.3 \pm 0.06 \mathrm{c}$ & $9 \pm 5.9 b$ & $3 \mathrm{c}$ \\
\hline $15-09-1$ & $2.1 \pm 0.75 \mathrm{ab}$ & $6.3 \pm 0.70 \mathrm{ab}$ & $1.5 \pm 0.06 \mathrm{~b}$ & $11.8 \pm 7.3 \mathrm{~b}$ & $3.3 \mathrm{bc}$ \\
\hline $8-08.3$ & $1.6 \pm 0.42 \mathrm{bc}$ & $5.7 \pm 1.03 \mathrm{~b}$ & $1.1 \pm 0.06 \mathrm{~d}$ & $15.5 \pm 6.0 \mathrm{ab}$ & $3.7 \mathrm{~b}$ \\
\hline $8-08-9$ & $1.1 \pm 0.44 \mathrm{c}$ & $5.0 \pm 0.55 b$ & $1.1 \pm 0.10 \mathrm{~d}$ & $17.8 \pm 6.4 \mathrm{ab}$ & $3.7 \mathrm{~b}$ \\
\hline $5-09-2$ & $0.8 \pm 0.30 \mathrm{c}$ & $4.6 \pm 0.20 b$ & $1.1 \pm 0.12 \mathrm{~d}$ & $11.3 \pm 8.3 b$ & $4.7 \mathrm{a}$ \\
\hline $5-09-1$ & $1.8 \pm 0.55 \mathrm{bc}$ & $6.0 \pm 0.55 b$ & $1.2 \pm 015 \mathrm{~cd}$ & $11.6 \pm 2.4 \mathrm{~b}$ & $3 \mathrm{c}$ \\
\hline
\end{tabular}

Note. ${ }^{1}$ - scores 1-9: 1 - no visible symptoms of infection, 9 - more than $75 \%$ damaged leaves; data are mean \pm SD across all years; in columns, different letters mark significant differences at $p \leq 0.05$.

Estonia (Kikas et al., 2019), Russia and Belorussia (Bohonova, 2004; Dmitriyeva, Korovin, 2008). Yield of genotypes was negatively related to GDD to beginning of ripening $(r=-0.34)$ and flower and young fruit drop $(r=-0.22)$. In terms of genotype averages, fruits were the smallest in $2017(1.1 \mathrm{~g})$, when the amount of GDD required for flowering was also the smallest; in 2016 and 2018 average fruit weight was similar $(1.3 \mathrm{~g})$. On average for the experimental years, the largest fruits were from the Nos 11-09-3 (1.7 g) and 7-08-2 (1.6 g), followed by genotypes Nos 7-08-1, 7-09-1, 15-09-1 and cultivar 'Mairi' (all $1.5 \mathrm{~g}$ ).

In previous experiments, cultivar 'Mairi' produced large fruit. The large-fruited 'Intercontinental' is the mother cultivar of genotypes Nos 7-08-1 and 7-08-2. These genotypes outyielded their mother cultivar. Fruit size is at the same level as that of the 'Intercontinental' but larger than that of the father 'Pamyat Vavilova' (Sasnauskas et al., 2009; Kikas et al., 2019). Genotype No. 3-08-1 outyielded the parental cultivars 'Ben Alder' and 'Titania' - the fruit size was larger than that of the parental cultivars (Kaldmäe et al., 2013; Pluta, Żurawicz, 2014; Mazeikiene et al., 2017 b). Genotype No. 15-09-1 has higher yield and larger fruits than that of the mother cultivar 'Asker' (Kikas et al., 2019). There was a mean positive relationship $(r=0.29$ and $r=0.32)$ between fruit weight and yield and fruit weight and GDD to fruit ripening, respectively. Experiments carried out elsewhere have produced different results. In Serbia, a weak positive correlation was found between fruit yield and weight (Rakonjac et al., 2015), and in Poland, a strong negative correlation was found (Madry et al., 2005).

Phytopathological and entomological traits. An important factor in the development of new cultivars is their resistance to diseases and pests, for blackcurrant cultivars resistance to gall mite, anthracnose and gooseberry mildew. Damage by the gall mite (Cecidophyopsis ribis Westw.) is very dangerous, as it can limit yield severely and is a biological vector blackcurrant reversion virus (BRV) (Mazeikiene et al., 2017 a; Mažeikienè et al., 2019). Gall mite occurred (2 score) only in the last testing year in genotype No. 6-09-1, and gooseberry mildew (Sphaerotheca mors-uvae Schw. Berk.) - only in the genotypes Nos 8-09-1 and 11-09-3 (2 and 3 scores, respectively). The damage by anthracnose (Drepanopeziza ribis Kleb.) was the weakest in 2016. On average throughout the years, damage by anthracnose was the weakest in No. 8-09-1 (2.3 scores) and the strongest in No. 5-09-2 (4.7 scores) (Table 4).

Chemical content of fruits of the best genotypes. Fruits of cultivar 'Mairi' had the highest soluble solids content (18.7), followed by genotypes Nos 8-09-3 and 3-08-1 (Table 5).

Table 5. The content of soluble solids, organic acids, ascorbic acid, anthocyanins and polyphenols in the fruits of blackcurrant genotypes

\begin{tabular}{|c|c|c|c|c|c|}
\hline Genotype No. & $\mathrm{SS}^{1}$ Brix $^{\circ}$ & $\mathrm{TA}^{1} \%$ & $\mathrm{AA}^{2} \mathrm{mg} 100 \mathrm{~g}^{-1}$ & $\mathrm{AC} \mathrm{mg} 100 \mathrm{~g}^{-1}$ & PP mg $100 \mathrm{~g}^{-1}$ \\
\hline 'Mairi' & $18.7 \pm 0.66 \mathrm{a}$ & $2.3 \pm 0.21 \mathrm{~d}$ & - & $194 \pm 57.3 b$ & $304 \pm 74.2 \mathrm{~b}$ \\
\hline $3-08-1$ & $15.9 \pm 1.51 \mathrm{~b}$ & $2.9 \pm 0.0 \mathrm{bc}$ & 127 & $147 \pm 20.3 \mathrm{~d}$ & $235 \pm 56.6 \mathrm{dc}$ \\
\hline $7-08-1$ & $14.7 \pm 1.2 \mathrm{~d}$ & $3.0 \pm 0.21 \mathrm{~b}$ & 137 & $164 *$ & $228^{*}$ \\
\hline $7-08-2$ & $14.5 \pm 1.25 \mathrm{c}$ & $2.9 \pm 0.26 b c$ & 89 & $175 \pm 4.9 \mathrm{c}$ & $268 \pm 36.1 \mathrm{c}$ \\
\hline $8-09-3$ & $15.9 \pm 0.9 \mathrm{~b}$ & $2.8 \pm 0.3 \mathrm{c}$ & 99 & - & $54.7 \pm 10.6 \mathrm{c}$ \\
\hline $15-09-1$ & $14.8 \pm 1.22 \mathrm{~d}$ & $3.2 \pm 0.15 \mathrm{a}$ & 208 & $273 \pm 9.9 \mathrm{a}$ & $400 \pm 13.4 \mathrm{a}$ \\
\hline
\end{tabular}

Note. SS - soluble solids, TA - titratable acids, AA - ascorbic acid, AC - anthocyanins, PP - polyphenols; ${ }^{1}-$ data are mean \pm SD across all years, ${ }^{2}-$ one-year data; in columns, different letters mark significant differences at $p \leq 0.01$. 
Titratable acid content was the lowest in the fruit of cultivar 'Mairi' and the highest of genotype No. 15-09-1. The content of ascorbic acid, anthocyanins and polyphenols was the highest in the fruits of genotype No. 15-09-1. The content of ascorbic acid was at the same level as that of the mother cultivar 'Asker' (Kaldmäe et al., 2013). Fruits of 'Mairi' contain $121 \mathrm{mg} 100 \mathrm{~g}^{-1}$ ascorbic acid (Kikas et al., 2017). Fruits of the greenfruited genotype No. 8-09-3 did not contain anthocyanins, and the content of ascorbic acid and polyphenols was relatively low.

\section{Conclusion}

1. The experiment revealed the best blackcurrant genotypes to be Nos: 3-08-1 ('Ben Alder' $\times$ 'Titania'), 7-08-1, 7-08-2 ('Intercontinental' $\times$ 'Pamyat Vavilova') and 15-09-1 ('Asker' free pollination), and the greenfruited No. 8-09-3 ('Öjebyn' $\times$ 'Mairi'). All these genotypes had higher or equal yield, number of fruits per cluster, weight of fruit compared to the standard cultivar 'Mairi'. These were all winter hardy and visually resistant to gall mite (Cecidophyopsis ribis Westw.) and gooseberry mildew (Sphaerotheca mors-uvae (Schw.) Berk.).

2 . The growing degree-days (GDD) required to start blackcurrant flowering and fruit ripening depended on both growing conditions and the genotype.

3. Genotype No. 3-08-1 was mid-ripening, produced good yield $\left(2.3 \mathrm{~kg} \mathrm{bush}^{-1}\right)$ and large fruit $(1.4 \mathrm{~g})$. It outyielded the parental cultivars 'Ben Alder' and 'Titania', but the fruits were larger than those of the parental cultivars.

4. Genotypes Nos 7-08-1 and 7-08-2 were mid- to late-ripening, produced good yield (2.5 and 2.3 $\mathrm{kg} \mathrm{bush}^{-1}$, respectively) and large fruit (1.5 and $1.6 \mathrm{~g}$, respectively). They outyielded the mother cultivar 'Intercontinental'; the size of the fruit was at the same level as that of the 'Intercontinental' and larger than that of the father cultivar 'Pamyat Vavilova'. Flower and young fruit drop was small.

5. Genotype No. 15-09-1 was mid-ripening, produced good yield $\left(2.1 \mathrm{~kg} \mathrm{bush}^{-1}\right)$ and large fruit $(1.5 \mathrm{~g})$. Flower and young fruit drop was small. The content of ascorbic acid (208 mg $\left.100 \mathrm{~g}^{-1}\right)$ was at the same level as that of the mother cultivar 'Asker', the amount of anthocyanins (273 mg $\left.100 \mathrm{~g} \mathrm{~g}^{-1}\right)$ and polyphenols (400 mg $\left.100 \mathrm{~g}^{-1}\right)$ in the fruits was high.

6. No. 8-09-3 was the best of the green-fruited genotypes. It is an early season genotype with average yield. Flower and young fruit drop was small. Farmers like this genotype, as it is good for wine making.

\section{Acknowledgements}

The authors want to thank the Estonian Ministry of Rural Affairs for the financial support for National Programme for Plant Breeding from 2009-2019 and 2020-2030.

We thank PlantValor laboratory staff $\mathrm{H}$. Kaldmäe, R. Rätsep and A. Aluvee for performing biochemical analyses, supported by the European Regional Development Fund. The authors are grateful to I. Williams for the English language correction, supported by Institutional Research Funding IUT36-2 of the Estonian Ministry of Education and Research.

Received 28032020 Accepted 04092020

\section{References}

Aydin Y., Yücel A., Atilgan A., Tanriverdi Ç. 2019. Determination of growing degree-day (GDD) values: pistachio (Pistacia vera L.) case. Series B, Horticulture, LXIII (2): 47-54.

Bohonova M. I. 2004. Peculiarities of growth and fruit bearing of blackcurrant cultivars. Plodovodstvo, 15: 71-74 (in Russian).

Brennan R. M. 2008. Currants and gooseberries. Hancock J. F. (ed.). Temperate fruit crop breeding. Springer, p. 177-196. https://doi.org/10.1007/978-1-4020-6907-9_6

Dalton D. T., Hummer K. E. 2010. Ribes bloom phenology: section Botrycarpum and Ribes. Journal of the American Pomological Society, 64 (3): 140-151.

Dmitriyeva A. M., Korovin K. L. 2008. Results of blackcurrant variety study in Belarus. Plodovodstvo, 20: 157-162 (in Russian).

Hummer K. E., Dale A. 2010. Horticulture of Ribes. Forest Pathology, 40: 251-263. https://doi.org/10.1111/j.1439-0329.2010.00657.x

Jarret D., Jennings N., Williams D., Graham J. 2020. Development and use of genetic tools in Rubus and Ribes breeding at James Hutton Institute/Limited. Acta Horticulturae, 1277: 1-10. https://doi.org/10.17660/ActaHortic.2020.1277.1

Kaldmäe H., Libek A.-V., Arus L., Kikas A. 2013. Genotype and microclimate conditions influence ripening pattern and quality of blackcurrant (Ribes nigrum L.) fruit. Zemdirbyste-Agriculture, 100 (2): 167-174. https://doi.org/10.13080/z-a.2013.100.021

Kikas A., Kahu K., Arus L., Kaldmäe H., Rätsep R., Libek A.-V. 2017. Qualitative properties of the fruits of blackcurrant Ribes nigrum L. genotypes in conventional and organic cultivation. Proceedings of the Latvian Academy of Sciences. B: Natural, Exact, and Applied Sciences, 71 (3): 190-197. https://doi.org/10.1515/prolas-2017-0032

Kikas A., Laurson P., Libek A.-V. 2019. Evaluation of Belorussian and Estonian blackcurrant Ribes nigrum L. cultivars in Estonia. Plodovodstvo, 31: 13-138.

Krüger E., Dietrich H., Hey M., Patz C. 2011. Effects of cultivar, yield, berry weight, temperature and ripening stage on bioactive compounds of black currants. Journal of Applied Botany and Food Quality, 84: 40-46.

Madry W. M., Kozak S., Pluta E., Zurawicz E. 2005. A new approach to sequential yield component analysis (SYCA): application to fruit yield in blackcurrant (Ribes nigrum L.). Journal of New Seeds, 7: 85-107. https://doi.org/10.1300/J153v07n01_07

Masny A., Pluta S., Seliga Ł. 2018. Breeding value of selected blackcurrant (Ribes nigrum L.) genotypes for early-age fruit yield and its quality. Euphytica, 214 (6): 1-21. https:// doi.org/10.1007/s10681-018-2172-9

Mazeikiene I., Bendokas V., Baniulis D., Staniene G., Juskyte A. D., Sasnauskas A., Stanys V., Siksnianas T. 2017 (a). Genetic background of resistance to gall mite in Ribes species. Agricultural and Food Science, 26 (2): 110-116. https://doi.org/10.23986/afsci.59410

Mazeikiene I., Stanys V., Juskyte A. D., Sasnauskas A., Siksnianas T. 2017 (b). Blackcurrant varieties 'Aldoniai' and 'Didikai'. Zemdirbyste-Agriculture, 36 (1-2): 7-14.

Mažeikienė I., Juškytė A. D., Stanys V. 2019. Application of marker-assisted selection for resistance to gall mite and blackcurrant reversion virus in Ribes genus. ZemdirbysteAgriculture, 106 (4): 359-366. https://doi.org/10.13080/z-a.2019.106.046

McMaster G. S., Wilhelm W. W. 1997. Growing degree-days: one equation, two interpretations. Agricultural and Forest Meteorology, 87 (4): 291-300. https://doi.org/10.1016/S0168-1923(97)00027-0 
Pedersen L. H. 2007. Black- and red currants cultivars for low pesticide production. NJF $23^{\text {rd }}$ Congress 2007. Trends and Perspectives in Agriculture, p. 188-189.

Pluta S., Pruski K. 2012. Suitability of fruits of selected black currant (Ribes nigrum L.) cultivars destined for fresh market. Journal of Berry Research, 2: 1-9. https://doi.org/10.3233/JBR-2011-025

Pluta S., Żurawicz E. 2014. 'Gofert' blackcurrant. HortScience, 49 (4): 513-515. https://doi.org/10.21273/HORTSCI.49.4.513

Rakonjac V., Djordjević B., Fotirić Akšić M., Vulić T., Djurović D. 2015. Estimation of variation and correlation analysis for yield components in black currant cultivars. Genetika, 47 (3): 785-794. https://doi.org/10.2298/GENSR1503785R

Sasnauskas A., Trajkovski V., Strautina S., Tikhonova O., Šikšnianas T., Rubinskiene M., Viškelis P., Lanauskas J., Valiuškaitė A., Rugienius R., Bobinas Č. 2009. Evaluation of blackcurrant cultivars and perspective hybrids in Lithuania. Agronomy Research, 7 (II): 737-743.

Sasnauskas A., Šikšnianas T., Stanys V., Viškelis P., Bobinaite R., Rubinskienè M., Bobinas Č. 2013. Agronomical characters of introduced new blackcurrant cultivars. Proceedings of the Latvian Academy of Sciences, Section B: 67 (2): 211-214. https://doi.org/10.2478/prolas-2013-0036
Stanys V., Bendokas V., Rugienius R., Sasnauskas A., Frercks B., Mažeikienè I., Šikšnianas T. 2019. Management of anthocyanins amount and composition in genus Ribes using interspecific hybridisation. Scientia Horticulturae, 247: 123-129. https://doi.org/10.1016/j.scienta.2018.12.014

Strautiņa S., Lācis G., Kampuss K. 2020. Phenotypical variability and diversity within Ribes genetic resources collection of Latvia. Acta Horticulturae, 1277: 81-88. https://doi.org/10.17660/ActaHortic.2020.1277.11

Williams R. C., Baker D. R., Smith J. A. 1973. Analyses of water-soluble vitamins by high-speed ion-exchange chromatography. Journal of Chromatographic Science, 11: 618-624. https://doi.org/10.1093/chromsci/11.12.618

Woznicki T. L., Heide O. M., Sønsteby A., Wold A.-B., Remberg S. F. 2015. Yield and fruit quality of black currant (Ribes nigrum L.) are favoured by precipitation and cool summer conditions. Acta Agriculturae Scandinavica, Section B: Soil and Plant Science, 65 (8): 702-712. https://doi.org/10.1080/09064710.2015.1052093

Yang B., Zheng J., Kallio H. 2010. Compositional variation in fruits of currants as function of genotypes and their interactions with growth environments. NJF Report, 6 (2): 45.

\title{
Perspektyvių juodojo serbento hibridų biologinių, ekonominių ir biocheminių savybių ịvertinimas Estijoje
}

\author{
A. Kikas, P. Laurson, A.-V. Libek \\ Estijos gyvybès mokslų universiteto Žemès ūkio ir aplinkos mokslų institutas
}

\begin{abstract}
Santrauka
Juodojo serbento (Ribes nigrum L.) perspektyvių hibridụ ịvertinimas buvo atliktas 2016-2018 m. Pietų Estijoje, Estijos gyvybės mokslų universiteto Polli sodininkystės tyrimų centre. Estijos juodojo serbento selekcinės programos tikslas - išvesti šalčiui ir serbentinei erkutei (Cecidophyopsis ribis Westw.) bei agrastų miltligei (Sphaerotheca mors-uvae (Schw.) Berk.) atsparias veisles, tinkamas derliaus mašininiam nuėmimui ir pasižyminčias geru derlingumu bei uogų kokybe. Eksperimento laukelis buvo ịrengtas $2014 \mathrm{~m}$. rudenị. Buvo įvertinti juodojo serbento 24 perspektyvūs hibridai iš Estijos juodujų serbentų selekcinės programos ir nauja estiška veislè 'Mairi' kaip standartinè. Nustatytos šios savybès: žydèjimo ir uogų nokimo pradžia (išreikšta aktyvių temperatūrų dienomis), atsparumas žiemojimui, ligoms ir kenkẻjams (1-9 balų skalèje), uogų skaičius vienoje kekëje, derlius (kg iš vieno krūmo), uogų svoris ir tirpių kietujų medžiagų kiekis ( ${ }^{\circ}$ Brix). Serbentų uogose tirta titruojamujjų rūgščių, askorbo rūgšties, antocianinų ir polifenolių kiekis. Tyrimo metu nustatyti geriausi juodojo serbento genotipai: Nr. 3-08-1 ('Ben Alder' × 'Titania'), 7-08-1, 7-08-2 ('Intercontinental' × 'Pamyat Vavilova') ir 15-09-1 ('Asker' - laisvai apsidulkinanti), žaliauogio serbento - Nr. 8-09-3 ('Öjebyn' × 'Mairi'). Šie genotipai yra atsparūs žiemojimui ir vizualiai atsparūs serbentinei erkutei bei agrastų miltligei. Pirmieji keturi genotipai davè gerą derlių ir užaugino dideles uogas.
\end{abstract}

Reikšminiai žodžiai: antraknozė, derlius, Ribes nigrum genotipai, uogų svoris, žiemkentiškumas. 